\title{
Morphometrics Analysis of Sagitta Otolith in Pool Barb, Puntius sophore (Hamilton, 1822)
}

\author{
Anju Rani ${ }^{1}$ Deepak Rai ${ }^{1} \quad$ Anil K. Tyor ${ }^{1}$ \\ ${ }^{1}$ Department of Zoology, Kurukshetra University, Kurukshetra, \\ Address for correspondence Anju Rani, Research Scholar, \\ Haryana, India \\ Department of Zoology, Kurukshetra University, Kurukshetra 136119, \\ Haryana, India (e-mail: thaakran2101@gmail.com).
}

J Morphol Sci 2019;36:85-90.

\begin{abstract}
Keywords

- linear regression

- otolith dimensions

- shape indices

Introduction The use of otolith morphometrics could prove to be a powerful tool in fish identification. The aim of the present study was to analyze the shape of the otolith in pool barb, Puntius sophore.

Materials and Methods To accomplish the present study, samples of various sizes were collected from the Yamunanagar and from the Faridabad fish markets in Haryana, India. The sagitta otoliths were extracted by making a horizontal cut across the head of the fish.

Results The independent $t$-test revealed no statistically significant difference between the values of otolith length and width of both the right and left otoliths $(p>0.05)$. Furthermore, various shape indexes, such as form factor (FF); circularity (C); rectangularity (REC), and aspect ratio (AR) were calculated, and the general shape of the otoliths of $P$. sophore was described as rectangular and less elongated. The otolith length $(\mathrm{OL})$ was found to be positively correlated with the $A R$, whereas the FF was found to be negatively correlated with REC and C. The present study expresses the relationship between the total length ( $\mathrm{TL}$ ) and the head length $(\mathrm{HL})$ of the fish with the $\mathrm{OL}$ and the otolith width (OW) by a linear regression model. The results depicted that the $\mathrm{OL}$ and the OW were linearly correlated to the $\mathrm{TL}$ and to the $\mathrm{HL}$ of the fish.

Conclusion The present study also provides a better understanding in identification of fish stock.
\end{abstract}

\section{Introduction}

Puntius sophore (Hamilton, 1822), commonly known as pool barb, stigma barb, and swamp barb, is a freshwater to brackishwater fish belonging to the cypriniformes order and to the cyprinidae family. ${ }^{1}$ Cypriniformes are the largest group of fishes, with an estimated number of $\sim 3,500$ species. ${ }^{2}$ Puntius sophore is widely distributed in inland waters of Asia, including Bangladesh, Pakistan, India, Nepal, Myanmar, Bhutan, Afghanistan, and China. This fish is benthopelagic (demersal), inhabiting rivers, streams, and ponds of plains. ${ }^{3}$ It is considered as a chief food source for poor people in Bangladesh, ${ }^{4}$ and is used as an aquarium fish. ${ }^{5}$ According to the red list (2010) of the International Union for Conservation of Nature (IUCN), the status of this fish is regarded as of least concern. ${ }^{6}$ However, studies from the Indian waters depicted that the fish is at lower

received

September 4, 2018

accepted

January 9, 2019
DOI https://doi.org/ 10.1055/s-0039-1683911. ISSN 2177-0298. risk to near threatened in the Western Ghat and in the Harike wetland, due to heavy fishing pressure. ${ }^{7,8}$ Otoliths are paired calcified, aragonitic mineralizations located in the inner ear of the fish, which contribute to audition and equilibrium. ${ }^{9,10}$ Amongst the three otoliths, the sagitta is the largest, followed by the astericus and by the lapillus. ${ }^{11}$ The otolith continues to grow throughout the life of the fish, and its growth generally follows an allometric increase with respect to fish size. ${ }^{12}$ The variations in the shape of the sagitta otolith are immense and are species specific, ranging from pinhead size to massive pieces of calcium carbonate $\left(\mathrm{CaCO}_{3}\right) \cdot{ }^{11}$ Due to its interspecific variations and larger size, the sagitta otolith has been used to estimate the taxon, age, size, migration, and feeding habits of fishes. ${ }^{10,13,14}$. Hence, knowledge of fish otolith morphometry is considered a valuable tool for the identification of the stock, ${ }^{15,16}$ population management, ${ }^{17}$ determination of diet

Copyright (c) 2019 by Thieme Revinter Publicações Ltda, Rio de Janeiro, Brazil

\section{License terms}

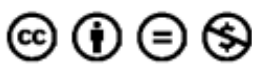


Table 1 Variables utilized to study otolith morphology 22

\begin{tabular}{|l|l|l|}
\hline Variables & Measurements & Description \\
\hline $\begin{array}{l}\text { Relative dorsal } \\
\text { length, (D) }\end{array}$ & d-d' & $D=\frac{d-d^{\prime}}{l-l^{\prime}} \times 100$ \\
\hline $\begin{array}{l}\text { Relative medial } \\
\text { length, (M) }\end{array}$ & $\mathrm{m}-\mathrm{m}^{\prime}$ & $A=\frac{m-m^{\prime}}{l-l^{\prime}} \times 100$ \\
\hline $\begin{array}{l}\text { Relative antirostrum } \\
\text { height, (A) }\end{array}$ & $\mathrm{m}-\mathrm{a}$ & $A-\frac{m-a}{h-h^{\prime}} \times 100$ \\
\hline $\begin{array}{l}\text { Relative rostrum } \\
\text { height, (R) }\end{array}$ & $\mathrm{m}-\mathrm{r}$ & $A L=\frac{m-r}{h-h^{\prime}} \times 100$ \\
\hline $\begin{array}{l}\text { Relative antirostrum } \\
\text { length, (AL) }\end{array}$ & al-d $\times 100$ \\
\hline $\begin{array}{l}\text { Relative rostrum } \\
\text { length, (RL) }\end{array}$ & $\mathrm{rl}-\mathrm{I}$ & $R L=\frac{r l-l}{l-l^{\prime}} \times 100$ \\
\hline
\end{tabular}

in predatory fishes, ${ }^{18}$ ontogenic research, ${ }^{19}$ ecomorphological studies, ${ }^{20}$ and for the identification of specific species. ${ }^{21}$

Although the otolith chemistry of marine fishes has been extensively studied, information on otolith of freshwater fishes concerning the Indian subcontinent is limited. Therefore, the purpose of the present study was aimed to analyze the shape and morphometrics measurements of the otolith of P. sophore.

\section{Materials and Methods}

A total of 41 specimens ranging between 66 and $109 \mathrm{~mm}$ in total length (TL) were procured from the fish markets of the Faridabad $\left(28.4211^{\circ} \mathrm{N}\right.$ and $\left.77.3078^{\circ} \mathrm{E}\right)$ and of the Yamunanagar $\left(30.133^{\circ} \mathrm{N}\right.$ and $\left.77.288^{\circ} \mathrm{E}\right)$ regions of Haryana, India, and brought to the laboratory in an ice box. All of the fish specimens were cleaned and measured for TL, standard length, HL, and body weight, nearest to $0.1 \mathrm{~mm}$ and $1 \mathrm{~g}$, respectively. The sagitta otoliths were removed by making a horizontal cut across the head of the fish. The otoliths were cleaned manually by using $1 \%$ potassium hydroxide $(\mathrm{KOH})$ solution to remove otic fluid, blood, and tissue, and were air
Table 2 Shape indices calculated using otolith morphometric parameters $^{23,24}$

\begin{tabular}{|l|l|l|}
\hline Parameters & Shape indices & Formulae \\
\hline Area $(\mathrm{Ar})$ & Aspect ratio (AR) & $\mathrm{OL} / \mathrm{OW}$ \\
\hline Perimeter (P) & Form factor (FF) & $4 几 \mathrm{Ar} / \mathrm{P}^{2}$ \\
\hline Otolith length (OL) & Rectangularity (REC) & $\mathrm{Ar} / \mathrm{OL} / \mathrm{OW}$ \\
\hline Otolith width (OW) & Circularity (C) & $\mathrm{P}^{2} / \mathrm{Ar}$ \\
\hline
\end{tabular}

dried. The right and left otoliths were kept separately in different labeled envelopes.

Digital images of both the right and left otoliths were obtained over a dark background using a Magnus MSZ-TR stereo microscope (Magnus Analytics, New Delhi, India (fitted with a Magcam DCS 5.1MP, 1/2.5" CMOS SENSOR camera. Various morphometric measurements of the otoliths, ${ }^{22}$ as shown in - Table 1, were acquired using ProgRes CapturePro, version 2.80, software (Jenoptik AG, Jena, Germany), in which the otolith length (OL) was the maximum distance from the rostrum to the postrostrum, and the otolith width (OW) was the distance perpendicular to the length passing through the dorsal and ventral rim (-Fig. 1).

For the analysis of the shape of the otoliths, morphometric parameters such as $\mathrm{OL}, \mathrm{OW}$, area $(\mathrm{Ar})$ and perimeter $(\mathrm{P})$ were utilized to calculate four dimensionless shape indices (form factor (FF); circularity (C); rectangularity (REC); and aspect ratio $(A R)^{23,24}$ ( - Table 2). Form factor is a mean to estimate the surface area irregularity, C gives information on the similarity of various features to a perfect circle, REC describes the variations of length and width with respect to the area, and AR expresses the shape tendency of the otolith. ${ }^{23}$ To statistically analyze the data, SPSS for Windows, Version 16.0(SPSS Inc, Chicago, IL, USA) and Microsoft Excel, version 2007 (Microsoft Corp., Redmond, WA, USA) were employed. The difference between the OL and the OW of the right and left otoliths was examined by employing the independent $t$-test. The relationship between the TL and the $\mathrm{HL}$ of the fish and the OL and OW was described by a linear equation.

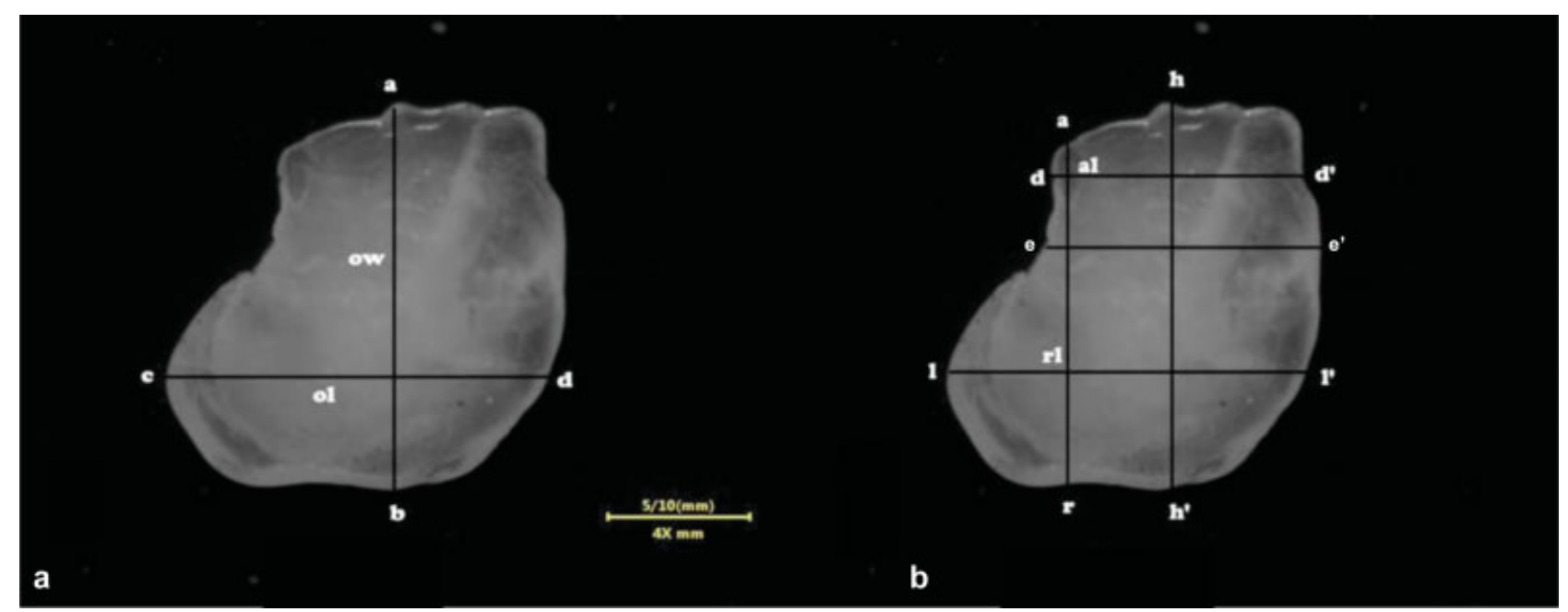

Fig. 1 Otolith of Puntius sophore (a) The distance between a and b is the otolith width, and the distance between c and d is the otolith length, (b) various otolith morphometric measurements used for the present study. 
Table 3 Mean, standard deviation, standard error, minimum and maximum values of various body measurements of Puntius sophore

\begin{tabular}{|l|l|l|l|l|l|}
\hline Parameter & Mean & SD & SE & Min & Max \\
\hline Total length (TL) & 83.9 & 10.4 & 1.6 & 66 & 109 \\
\hline Standard length (SL) & 67.5 & 8.6 & 1.3 & 52 & 89 \\
\hline Head length (HL) & 15 & 2.1 & 0.3 & 12 & 20 \\
\hline Body weight (BW) & 104 & 36.9 & 5.8 & 40 & 210 \\
\hline
\end{tabular}

Abbreviations: Max, maximum range; Min, minimum range; SD, standard deviation.

All of the values depicted in the table are in millimeters $(\mathrm{mm})$

Table 4 Mean, standard error, minimum and maximum values of various parameters of otolith dimensions

\begin{tabular}{|l|l|l|l|}
\hline Parameters & Mean \pm SE & Min & Max \\
\hline Otolith length (OL) & $0.74 \pm 0.1$ & 0.54 & 1.07 \\
\hline Otolith width (OW) & $0.91 \pm 0.0 .2$ & 0.61 & 0.98 \\
\hline $\begin{array}{l}\text { Relative antirostrum } \\
\text { height (A) }\end{array}$ & $28.8 \pm 1.68$ & 14.03 & 65.74 \\
\hline $\begin{array}{l}\text { Relative antirostrum } \\
\text { length (AL) }\end{array}$ & $8.51 \pm 0.60$ & 17.89 & 2.75 \\
\hline $\begin{array}{l}\text { Relative rostrum } \\
\text { height (R) }\end{array}$ & $55.4 \pm 2.05$ & 18.10 & 75.79 \\
\hline $\begin{array}{l}\text { Relative rostrum } \\
\text { length (RL) }\end{array}$ & $14.3 \pm 1.25$ & 4.53 & 33.27 \\
\hline
\end{tabular}

Abbreviations: Max, maximum range; Min, minimum range; SE, standard error.

All the values depicted in table are in millimeters $(\mathrm{mm})$.

\section{Results}

A total of 82 otolith samples were collected from 41 specimens. The OLs and OWs ranged between 0.54 and $1.07 \mathrm{~mm}$, and between 0.61 and $0.98 \mathrm{~mm}$, respectively. Various morphometric parameters of the fish were taken into consideration (-Table 3). The measurements of Otolith length (OL) and otolith width (OW) of both right and left otoliths were tested and no statistically significant difference was observed ( $p>0.05)$. Therefore, either the left or right sagitta otolith can be used for the analysis. For the present study, the left sagitta otolith was utilized. The shape of the otolith of $P$. sophore was described as rectangular and less elongated, possessing well-defined antirostrum and rostrum. The antirostrum was observed as short and narrow, with average height and length of $28.8 \pm 1.68$ and $8.51 \pm 0.60 \mathrm{~mm}$, respectively, whereas the rostrum was noticed to be wide and round with a mean height and length of $55.4 \pm 2.05$ and $14.3 \pm 1.25 \mathrm{~mm}$, respectively (-Table 4 ). The otolith has smooth dorsal and ventral margins with an obtuse excisural notch. The sulcus was found to be round and deep (-Fig. 2b). By comparing the mean values of 4 shape indices of the otolith of $P$. sophore (-Table 5), it was concluded that the average value of REC was the highest, while the value of AR was the lowest (AR: $0.82<\mathrm{C}$ : $1.36<\mathrm{FF}$ : $31.91<\mathrm{REC}$ : 34.03). Furthermore, the OL was found to be positively correlated with the AR, whereas the FF was found to be negatively correlated with REC and $\mathrm{C}$. The present study explains the relationship between the TL and the HL of the fish with the OL and the OW described by the linear equations $\mathrm{y}=0.0052 \mathrm{x}+0.309$ (-Fig. 3a); $\mathrm{y}=0.0095 \mathrm{x}$ +0.1114 (-Fig. 3b); $\mathrm{y}=7.2851 \mathrm{x}+9.5285$ (-Fig. 3c), respectively. The results depicted that the $\mathrm{OL}$ and the $\mathrm{OW}$ were linearly correlated to the TL and to the HL of the fish.

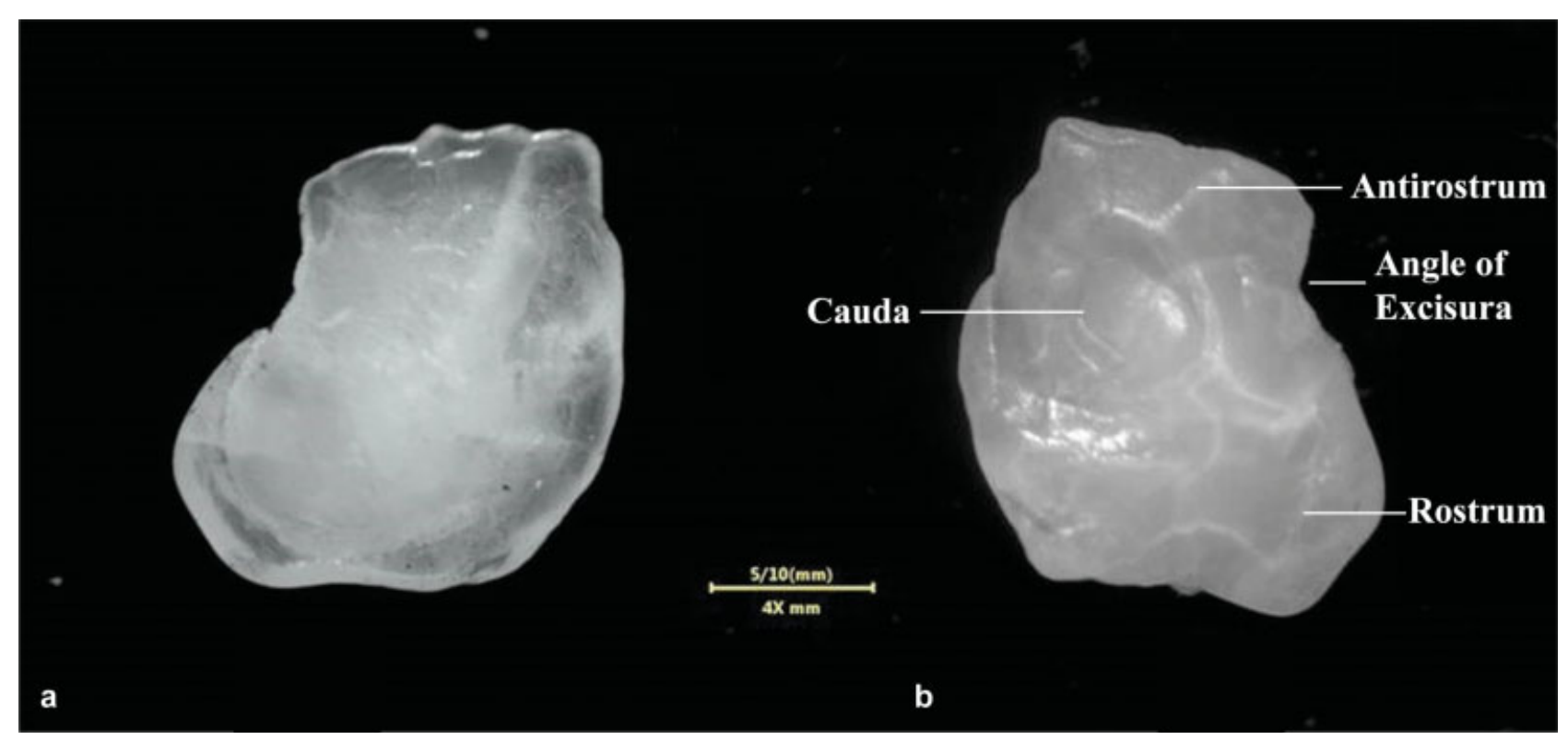

Fig. 2 Puntius sophore otolith (a) dorsal view of the left sagitta otolith, (b) ventral view of left sagitta otolith showing the cauda, the rostrum, the antirostrum, and the angle of excisura. 
Table 5 Descriptive statistics of shape indices of Puntius sophore

\begin{tabular}{|l|l|l|l|l|l|}
\hline Shape indices & Mean & SD & SE & Min & Max \\
\hline Form factor & 31.91 & 5.20 & 0.81 & 0.31 & 34.57 \\
\hline Aspect ratio & 0.82 & 0.1 & 0.02 & 0.61 & 0.98 \\
\hline Rectangularity & 34.03 & 2.57 & 0.40 & 28.52 & 39.86 \\
\hline Circularity & 1.36 & 3.93 & 0.61 & 2.35 & 27.72 \\
\hline
\end{tabular}

Abbreviations: Max, maximum range; Min, minimum range; SD, standard deviation; SE, standard error.

The OW was found to be a better parameter in estimating fish length than the OL.

\section{Discussion}

Otolith morphology has proven to be a powerful and vital tool in various taxonomic studies. Among the three otoliths, the sagitta otolith has been extensively utilized in various taxonomic studies related to age, growth, feeding habits, and stock identification, due to its larger size and great interspecific variability. ${ }^{10,13,14,25}$ The present study has aimed to examine the relationship of fish TL and HL with otolith dimensions (OL and $\mathrm{OW}$ ) by a linear regression model. The otolith dimensions (OL and OW) and fish body relationships have been studied in various marine fish species by linear regression models. ${ }^{15,26-32}$ The results of the present study depicted that the
OL and the OW were linearly correlated to the TL of the fish. The HL of the fish also showed positive correlation with the OL. The OW was found to be a better parameter than the OL in estimating fish length. Hence, it is suggested that otolith dimensions increase as fish length increase and, therefore, otolith growth can be correlated with fish growth. These results are similar to previous studies. ${ }^{33,34}$. However, other studies depicted that the relationship of otolith variables and fish somatic growth are not necessarily linear. ${ }^{35,36}$ In studies on the relationship between otolith and fish size, the OL was usually used. ${ }^{15,26,37-39}$ The present study supplies supplementary information by considering both the OL and the OW, as well as the HL of the fish. The present study also described various other morphometric parameters to give a detailed observation of the shape of the otolith. When comparing the values of the OL and of the OW of both right and left otoliths, no statistically significant difference was observed, which was consistent with the previous findings of different authors. $^{29,32,35,40}$ But some studies of sciaenid fishes, such as Micropogonias furnieri and Macrodon ancylodon, and of teleost fishes, such as Lycodes palearis (Zoarcidae) revealed inverse findings. ${ }^{15,41}$ Concerning the findings of the present study, it becomes evident that the knowledge of the otolith morphometrics is considered an important marker in the identification of species and in many other ecological studies that aimed to determine the prey size based on otoliths obtained from the stomach contents of piscivorous predators, because, when the relationship between the OL and the TL in a
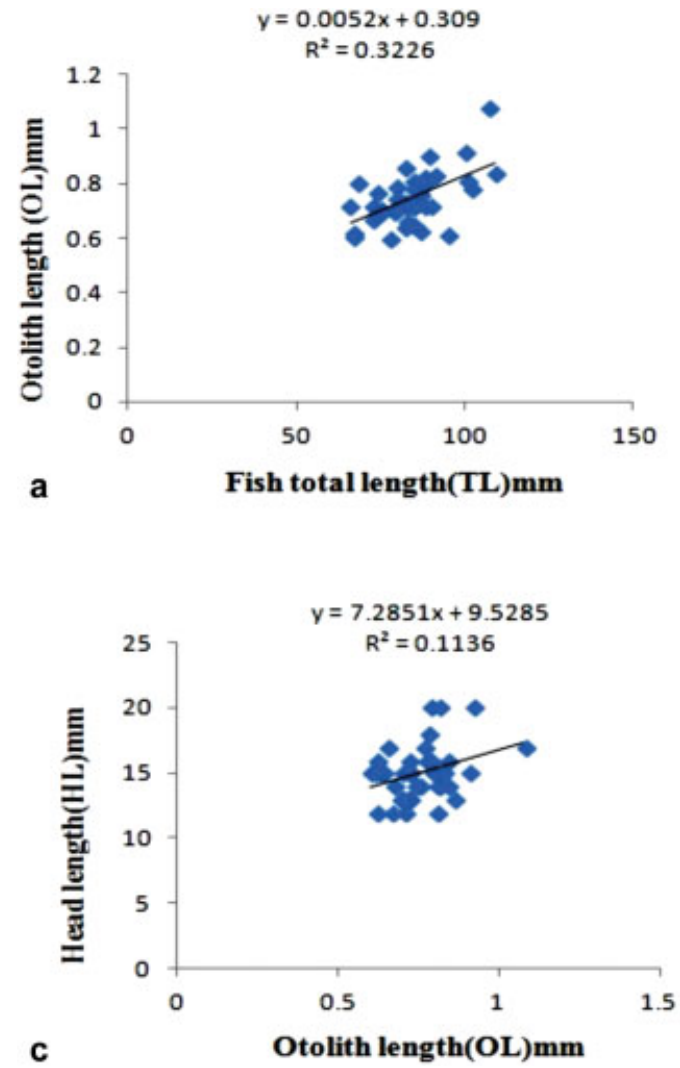
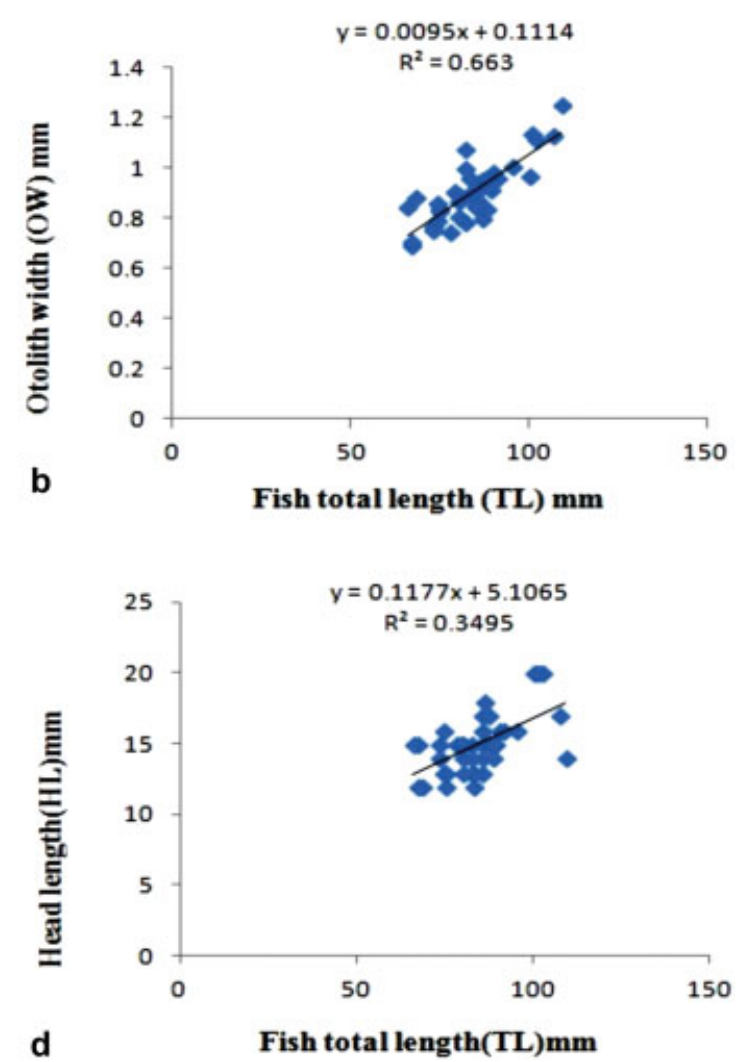

Fig. 3 Relationship between (a) otolith length and fish total length, (b) otolith width and fish total length, (C) head length and otolith length, and (d) head length and fish total length. 
species is determined, the TL or standard length of a fish can be easily estimated from its OL, or vice versa. ${ }^{28,31,33}$ The present study also provides a better understanding in the identification of the stock.

\section{Conflicts of Interest}

The authors have no conflicts of interest to declare.

\section{Acknowledgments}

The authors are highly grateful to the Department of Zoology of the Kurukshetra University, Kurukshetra, India, for providing the necessary laboratory facility for the accomplishment of the present study. The authors are also thankful to the local fishermen for providing suitable help during the sampling.

\section{References}

1 Redie K. Global register of migratory species from global to regional scales. Final report of R\&D Project 80805081 . Bonn, Germany: Fedral Agency for Nature Conservation; 2004:330

2 Nelson JS. Fishes of the World. 4th ed. Hoboken, NY, USA: John Wiley \& Sons, Inc.; 2006

3 Menon AGK. Check list - fresh water fishes of India. Rec ZoolSurv India. 1999;175:234-259

4 Roos N, Leth T, Jakobsen J, Thilsted SH. High vitamin A content in some small indigenous fish species in Bangladesh: perspectives for food-based strategies to reduce vitamin A deficiency. Int J Food SciNutr 2002;53(05):425-437

5 Froese R, Pauly D. EDS. http://www.fishbase.org2011

6 Dahanukar NPuntiussophore. The IUCN Red List of Threatened Species 2010; e.T166623A6249514.

7 Balasundaram C, Arumugam R, Murugan PB. Fish diversity of Kolli hills, Western Ghats, Salem district, Tamil Nadu. Zoos' Print. 2000;16(1):403-406

8 Dua A, Parkash C. Distribution and abundance of fish populations in Harike wetland-a Ramsar site in India. J Environ Biol 2009;30 (02):247-251

9 Popper AN, Ramcharitar J, Campana SE. Why otoliths? Insights from inner ear physiology and fisheries biology. Mar Freshw Res 2005;56:497-504

10 Mendoza RPR. Otoliths and their applications in fishery science. Ribarstvo 2006;64(03):89-102

11 Paxton JR. Fish otoliths: do sizes correlate with taxonomic group, habitat and/or luminescence? Philos Trans R SocLond B BiolSci 2000;355(1401):1299-1303

12 Chilton DE, Beamish RJ. Age determination methods for fishes studied by the groundfish program at the Pacific Biological Station.Ottowa. Can Spec Publ Fish AquatSci 1992;60:1-102

13 Campana SE. 20050tolith elemental composition as a natural marker of fish stocks. In Stock Identification Methods Applications in Fishery Sciences, edited by Cadrin SX, Friedland K, Waldman JR. Massachusetts: Elsevier Academic Press; 227-245

14 Morat F, Banaru D, Merigot B, et al. Relationship between Fish Length for nine teleost from Mediterranean basin, Kerguelen Islands and Pacific ocean. Cybium 2008;32:265-269

15 Harvey JT, Oughlin TR, Perez MA, Oxman DS. Relationship between fish size and otolith length for 63 species of fishes from the eastern North Pacific Ocean. NOAA Technical Report 2000;150:1-36

16 Campana SE, Thorrold SR. Otoliths, increments, and elements: Keys to a comprehensive understanding of fish populations? Can J Fish AquatSci 2001;58:30-38

17 Vasconcelos J, Vieira AR, Sequeira V, Gonzalez JA, Kaufmann M, Serrano Gordo L. Identifying populations of the blue jack mack- erel (Trachurus picturatus) in the Northeast Atlantic by using geometric morphometrics and otolith shape analysis. Fish Bull 2018;116:81-92

18 Lilliendahl K, Solmundsson J. Feeding ecology of symparic Eupropean shags Phalacrocorax artistotelis and great cormorants P. carbo in Iceland. Mar Biol 2006;149:979-990

19 Capoccioni F, Costa C, Aguzzi J, Menesatti P, Lombarte A, Ciccotti E. Ontogenetic and environmental effects on otolith shape variability in three Mediterranean European eel (Anguilla anguilla, L.) local stocks. J Exp Mar Biol Ecol 2011;397(01):1-7

20 Tuset VM, Piretti S, Lombarte A, Gonzalez JA. Using sagittal otoliths an deye diameter for ecological characterization of deep-sea fish: Aphanopus carbo and A. intermedius from NE Atlantic waters. Sci Mar 2010;74:807-814

21 Bani A, Poursaeid S, Tuset VM. Comparative morphology of the sagittal otolith in three species of south Caspian gobies. J Fish Biol 2013;82(04):1321-1332

22 Reichenbacher B, Sienknecht U, Küchenhoff H, Fenske N. Combined otolith morphology and morphometry for assessing taxonomy and diversity in fossil and extant killifish (Aphanius, Prolebias). J Morphol 2007;268(10):898-915

23 Tuset VM, Lombarte A, González JA, Pertusa JF, Lorente MJ. Comparative morphology of the sagittal otolith in Serranus spp.. J Fish Biol 2003;63(06):1491-1504

24 Lord C, Morat F, Lecomte-Finiger R, Keith P. Otolith shape analysis for three Sicyopterus (Teleostei: Gobioidei: Sicydiinae) species from New Caledonia and Vanuatu. Environ Biol Fishes 2012;93 (02):209-222

25 Rodgveller CJ, Hutchinson CE, Harris JP, Vulstek SC, Guthrie CM. Otolith shape variability and associated body growth differences in giant grenadier, Albatrossiapectoralis. PLoS One 2017;12(06): e0180020

26 Şen D, Aydin R, Çalta M. Relationships between fish length and otolith length in the population of Capoetacapoetaumbla (Heckel, 1843) inhabiting Hazar Lake, Elazig, Turkey. Arch Pol Fisheries 2001;9:267-272

27 Bostanci D. Otolith biometry-body length relationships in four fish species (chub, pikeperch, crucian carp, and common carp). J FreshwatEcol 2009;24:619-624

28 Battaglia P, Malara D, Romeo T, Andloro F. Relationships between otolith size and fish size in some mesopelagic and bathypelagic species from Mediterranean Sea (Strait of Messina, Italy). Sci Mar 2010;74:605-612

29 Jawad LA, Ambuali A, Al-Mamyr JM, Albusaidi HK. Relationships between fish length and otolith length, width and weight of the Indian mackerel Rastrelligerkanagurta(Cuvier, 1817) collected from the Sea of Oman. Ribarstvo 2011;69(2):51-61

30 Bostanci D, Yilmaz S, Polat N, Kontas S. The otolith biometry characteristics of black scorpionfish, Scorpaenaporcus, 1758.The Black Sea.International. J Engineering Science 2012;2:59-68(in Turkish)

31 Basusta A, Bal H, Aslan E. Otolith biometry - total length relationships in the population of Hazar Bleak, Alburnusheckeli (Battalgil, 1943) inhabiting Lake Hazar, Elazig, Turkey. Pak J Zool 2013; 45:1180-1182

32 Félix VR, Martínez-Pérez JA, Molina JR, Emiliano R, Zuñiga Q, López JF. Morphology and morphometric relationships of the sagitta of Diapterusauratus (Perciformes: Gerreidae) from Veracruz, Mexico. Rev Biol Trop 2013;61(01):139-147

33 Yilmaz S, Yazicioglu O. Saygin (Ayaydin) S, Polat N. Relationships of otolith dimensions with body length of European perch, Percafluviatilis L, 1758 from Lake Ladik, Turkey. Pak J Zool 2014;46:1231-1238

34 Yilmaz S, Yazicioglu O, Yazici R, Polat N. Relationships between fish length and otolith size for five cyprinid species from Lake Ladik, Samsun,Turkey. Turk J Zool 2015;39:438-446

35 Dehghani M, Kamrani E, Salarpouri A, Kamali E. Age and growth of Sind sardine (Sardinellasindensis) using otolith 
90 Morphometrics Analysis of Sagitta Otolith Rani et al.

from Qeshm Island (Persian Gulf). Iran J Fish Sci 2015;14(1): 217-231

36 Campana SE. Photographic atlas of fish otoliths of the northwest atlantic ocean. Ottawa: NRC Research Press; 2004

37 Echeverria TW. Relationship of otolith length to total length in rockfishes from northern and central California. Fish Bull 1987; 85:383-387

38 Gamboa DA. Otolith size versus weight and bodylength relationships for eleven fish species of Baja California, Mexico. Fish Bull 1991;89:701-706
39 Şahin T, Güneș E. Relationship between otolith and total lengths of flounder (PleuronectesflesusluscusPallas, 1811) collected in eastern Black Sea coasts of Turkey. Turkish Journal of Maritime and Marine Sciences 1998;4:117-123

40 Škeljo F, Ferri J. The use of otolith shape and morphometry for identification and size-estimation of five wrasse species in predator-prey studies. J Appl Ichthyology 2012;28:524-553

41 Waessel JA, Lasta CA, Bavero M. Otolith morphology and body size relationship for juvenile sciaenidae in the rio de la plate esturay (35-36º ). Sci Mar 2003;67(02):233-240 